\title{
Civilisations
}

Revue internationale d'anthropologie et de sciences

humaines

$54 \mid 2006$

Expériences de recherche en République

démocratique du Congo

\section{War and Social Research}

The limits of empirical methodologies in war-torn environments

\section{Koen Vlassenroot}

\section{(2) OpenEdition}

\section{Journals}

Electronic version

URL: http://journals.openedition.org/civilisations/442

DOI: $10.4000 /$ civilisations.442

ISSN: 2032-0442

\section{Publisher}

Institut de sociologie de l'Université Libre de Bruxelles

\section{Printed version}

Date of publication: 1 April 2006

Number of pages: 191-198

ISBN: 2-87263-006-6

ISSN: 0009-8140

Electronic reference

Koen Vlassenroot, « War and Social Research», Civilisations [Online], 54 | 2006, Online since 01 April 2009, connection on 15 November 2019. URL : http://journals.openedition.org/civilisations/442 


\title{
War and Social Research \\ The limits of empirical methodologies in war-torn environments
}

\author{
Koen VLASSENROOT
}

Summary: Empirical observation in conflict situations is limited by numerous constraints. The most obvious are accessibility and security. This article, however, wants to challenge the dominant view that research in regions that are prone to violence and conflict is impossible because of the high security risks and therefore should be limited to postconflict situations or to situations where hostilities have ceased. It argues that the dynamic character of patterns of violence can also offer opportunities to researchers. Successful research in conflict regions is not conditioned by the level of insecurity as such, but by researchers' abilities to adapt to the conflict environment, their contacts with local actors or partners, their understanding of the conflict and on the flexibility in the used methodological tools. Based on experiences in South Kivu and Ituri, the article also claims that research is influenced by the relationship between the researcher and the research subject and by the autonomy of the researcher. Although both issues risk putting considerable constraints on social research, they become all the more relevant when working in conflict situations.

Key-words: violence, political economy of conflict, personal security, Ituri, Kivu.

Résumé : L'observation empirique dans les situations de conflit est soumise à de nombreuses contraintes dont les plus manifestes sont l'accessibilité et la sécurité. Cet article remet cependant en cause l'opinion dominante selon laquelle il est impossible de travailler dans un tel contexte (pour des raisons de sécurité) et recommandant de se limiter à des études après la cessation des hostilités ou la fin du conflit. Il démontre que le caractère dynamique des formes de violence offre un intérêt pour le chercheur. Le succès de la recherche n'est pas tant conditionné par le niveau d'insécurité que par la capacité $d u$ chercheur à s'adapter à l'environnement, ses contacts avec les acteurs locaux, sa compréhension du conflit et sa flexibilité méthodologique. Basé sur des expériences au Sud Kivu et en Ituri, l'article souligne que la recherche est influencée par le rapport que le chercheur entretient avec le sujet d'étude et par son autonomie : ces deux variables, qui exercent leurs effets dans toutes les recherches sociales, deviennent particulièrement saillantes dans les situations de conflit.

Mots-clés : violence, économie politique des conflits, sécurité personnelle, Ituri, Kivu. 


\section{The Limits of Fieldwork}

I t has become conventional wisdom that research in conflict zones is impossible because of the high security risks. As it is presumed that lack of security guarantees strongly limits the possibilities of researchers to collect valid data, more and more funds for academic research reject proposals that include fieldwork in conflict regions. Such research, it is argued, should be limited to post-conflict situations or to situations where hostilities have ceased. The consequences of this argument should not be underestimated: knowledge and understanding of conflict regions tends to be reduced to pre-war levels and conflict dynamics, to be misunderstood or not known at all. The same security constraints provide many actors with a perfect excuse to no longer invest in conflict research, thus reducing the knowledge about contemporary conflicts.

This article challenges this dominant view on research in conflict zones and argues that it is indeed possible to conduct research in regions that are prone to violence and conflict. Even if conflicts for researchers create a very volatile and insecure context, the dynamic character of patterns of violence can also offer some opportunities. The success of research does not only depend on the level of insecurity. It also depends on the position of the researcher, his of her contacts with local actors or partners, his or her understanding of the conflict, and most importantly, on the flexibility of the methodological tools used. Recent research carried out by scholars in conflict regions such as Sierra Leone, Somalia, northern Uganda, Indonesia, and Afghanistan have successfully challenged the conventional wisdom about the possibilities to do research in places where accessibility is limited by security constraints. Most of these studies characterize their flexible research methodologies, knowledge of the context and networks of local contacts.

Research in the eastern parts of the DRC is no exception to this. The Congolese conflict, which started in 1996 in a number of regions in the east continues to loom. At first sight this seems to strongly limit research opportunities. As a consequence, the arguments of inaccessibility and insecurity have been used by donors (research funds as well as humanitarian agencies) to limit their investment in academic research programs and action research. Nevertheless, even in the most war-torn regions, such as Ituri or some parts of the Kivus, a number of research opportunities continue to exist. The effects of limited accessibility can be reduced by adapting flexible research methodologies or by investing in a local network of resource contacts. These contacts must help to make informed security decisions and to identify those research topics and subjects that are not too sensitive (and thus do not put at risk local communities or informants). As a consequence, this network not only should include local informants and resource persons, but also people that can help the researcher to get access to certain regions and communities, or can offer the necessary protection once you leave the areas under control of MONUC forces. The question, as a researcher, is where to start building this network. In regions such as Ituri, where everyone has become everyone's enemy, those that decide about accessibility often are also those that are responsible for the high levels of violence. Once you seek contact with one of these groups, access to regions under control of other groups risks becoming a very arduous task. My experience learns that openness about the research objectives is the best strategy to guarantee acceptance by all groups. Getting this 
acceptance, which is a prime condition to successful research, is one of the most difficult parts of the research strategy. It takes a lot of time to detect who are the true leaders of a local community, and thus who are to be convinced. Based on experiences in South Kivu and Ituri, I therefore want to argue that research in conflict regions is strongly influenced by the relationship between the researcher and the research subject and by the autonomy of the researcher. Although both issues risk putting considerable constraints on all social research, they become all the more relevant when working in highly charged political and conflict situations.

\section{Dynamics of War: Conflict and social transformation in eastern Congo}

In his analysis of ethics and accountability of researchers in conflict zones, Jonathan Goodhand states that "war zone researchers should be aware of the danger of "conflict fetish', the automatic assumption that violence is the problem and the only lens through which to look at people's lives" (Goodhand 2000: 15). He adds that "those affected by conflict frequently remind researchers and aid workers that there are other aspects to their lives, that war is not the only point of reference" (ibid.). In order to avoid being too much guided by the high levels of violence, my own research in the Kivus and Ituri has concentrated on the underlying social dynamics, or the ways in which war has reshaped structures of opportunity and meaning at the level of grassroots interaction. By contrast with traditional perspectives that have explained the Congolese conflict in terms of dynamics set in motion "from above", this research has stressed the local, "microlevel" dilemmas of conflict and development that continue to face communities living in the eastern parts of the DRC. The underlying hypothesis of this research was that conflicts tend to produce significant processes of social transformation, characterised by intensified struggles for access to local resources, a territorialisation of ethnicity around vital economic assets, shifts in local authority structures and the establishment of new informal structures of governance.

In order to analyse this process of social transformation in eastern Congo, it was first necessary to present war not as an irrational, abnormal event or as a sort of breakdown in a particular system, but as a complex of dynamics that is an expression of the inner logic of the existing local social and political order. The aim of this approach was to give meaning to the use of violence, which was understood as a means to reorganise the local social and economic space, and to control mobility within and between spaces. War was understood as an effort to concentrate violence in manageable and exchangeable forms. The main advantage of this perspective was that it has avoided being too much attracted by the "conflict fetish" but instead has concentrated on strategies developed as a response to growing insecurity at all levels of society. In recent conflict analysis, it is argued that violence offers opportunities both as strategies of survival for state actors and as strategies of resistance for a new class of local and regional strongmen. Rather than simply disrupting or destroying the local social and economic fabric, war is creating new opportunities for some even as it takes them away from others. The question then was, to explain how these dynamics of war have led to the formation of new centres of power and control, and how they have set in motion processes of social transformation.

The best strategy to answer this question was to analyse how the pre-war society of eastern Congo was organised and what was locally experienced as normal. If exclusion was the key to understanding the behaviour of those opting for a logic of violence in order to bring about change, I had to come to terms with the structural characteristics and 
processes of the local societies that have delineated the conditions of everyday life and have produced this exclusion. These characteristics and processes where the result of a historical process, so it was needed to reconstruct local history. It was my conviction that the grievances for conflict had to be situated within this process. Therefore, I opted for a research strategy that combined classical historical analysis based on archives with the collection of local narratives about people's own history. It was one of the outcomes of my research that the differences between the collected narratives were largely the result of one's ethnic identity. For members of the Banyamulenge community, these narratives stressed their political (and to a lesser extent economic) marginalisation. Members of some autochthonous communities lay emphasis on the struggle for land while others pointed at the collapse of the Zairian state. Collecting these narratives had the advantage that both the causes and key-moments of tension within local society could be identified and contextualised, which was a first step towards a better understanding of local conflict dynamics.

A next step was the analysis of those processes that have led to the transformation of the local political, social and economic space and have reshaped the way the grassroots population lives today. Here again, to research these processes I have opted for a focus on the actual behaviour of the different actors and the ways in which they explained this behaviour, rather than trying to provide an "objective" presentation of local events. While it sounds obvious that this was needed to investigate the content shifts in the particular links between local strongmen and their constituent communities, between warlords and their militia members, between economic actors and the local miners, between the traditional authorities and the rural population, it would have been misleading to focus only on elite strategies. As a local Congolese proverb says, "until the lions have their own historians, tales of hunting will always glorify the hunter". To avoid too much of a hunter's glorification, I had to integrate a grassroots perspective into the scope of analysis.

\section{Flexible Methodologies}

Therefore, I wanted to provide a space for the voices of individuals (telling their own stories and explaining their ideas and motivations in their own terms), something that has not appeared in the recent literature on eastern Congo and is also lacking in most contemporary conflict analysis. Aside from interviews with key people such as local political leaders, traditional authorities, university professors, civil society members, external observers, etc. I also talked to farmers, landless or unemployed youngsters, urban populations struggling for their own survival and internally displaced people. Rather than a quantitative survey, I aimed at collecting as many different accounts as possible. The aim of this method was mostly to come to a deeper insight into how people understand their changing political, social, cultural and economic environment and how they try to deal with it. For this purpose I have used a number of techniques that all belong to the methodological family of interviewing. Rather than a method collecting "standardised and reliable" data, I have opted for the technique offered by the "interactionist approach" of qualitative research, which "considers the respondents as experiencing subjects who actively construct their social worlds, and the primary issue here is to generate data which give an authentic insight into people's experiences" (Jacquemin 1999: 304).

This methodology, which was primarily ethnographic, combined half-open interviews with various stakeholders at the middle-range level (traditional and political authorities; military and rebel leaders; economic operators - including businessmen, mineral and 
commodity traders, former industrialists and bankers, operators represented by the Fédération des Entrepreneurs Congolais; representatives of civil society - including local NGOs, and the bureaux de la société civile) and individual or group interviews at the grassroots level (including petty traders; agriculturists; boutiquiers; traficants, vendors of primary and other commodities). Stakeholders at the middle-range level were identified through a snowball sampling approach with respect to the desired information (Atkinson and Flint 2001). In its simplest formulation, this snowball sampling consists of identifying respondents who are then used to refer researchers on to other respondents. It thus provides a useful means to access vulnerable and more impenetrable social groupings, or to identify the gatekeepers to a community.

The questions that were asked focused on four issues: (i) the problem of land acquisition and access to resources or the links between problems related to land and resource access and the eruption of violent conflict; (ii) the problem of economic competition or the continuities and discontinuities in the interaction between existing economic networks, and the connections of these relations to the local, regional and international dimensions of the conflict; (iii) the problem of political competition or the ways in which the war has affected patterns of political competition and local structures of authority; and (iv) the issue of societal transformation or the ways in which violent conflict has affected the existing societal fabric, and what has been its influence on elements like communal solidarity, relations between and within ethnic communities, etc. Questions that were asked related to these four issues, but the guide d'entretien was adapted to the identity of the respondents. Local farmers were mainly asked about their access to land, relations with their neighbors and patterns of solidarity. During group interviews, it was observed that these farmers told totally different stories when they were belonging to different ethnic groups than when they all had the same ethnic identity. Rebel leaderships were asked about their political ambitions, their perspectives on the conflict and their own solutions. Here it was much more difficult to find out what they really thought, let alone to ask the questions that I had in mind. Most of the times, these individuals just started talking and ignored my attempts to ask questions. Being a Belgian researcher, these interviews also often arrived at a discussion about the role of the Belgian colonial administration. Militia members were asked about their reasons for their enrollment, their social backgrounds, their dreams, etc. These interviews were the most difficult to realize, as these combatants in most cases were the opposite of their commanders; it took a lot of time and energy to get them talking, except when it came to military affairs. In all interviews, however, the focus was on the strategies that were developed by the respondents since the start of the war, and how the choice of these strategies was explained.

This approach came close to the general objectives of the livelihoods approach, which has recently also found its application to contemporary conflicts. At its basics, a livelihoods approach takes as its analytical starting point the actual lives of people, as well as the different strategies they use to achieve the outcomes they seek. Apart from the physical aspects of livelihood survival, crucial importance is also given to the political nature of livelihood opportunities, which involve the essential elements of both entitlement and access to capital, labour and resources. So, rather than starting from the perspective of a grand economic theory, a livelihood approach looks at where people are, what they have, what their needs and interests are, and it evaluates the strategies they use within the broader political and economic framework to achieve their desired outcomes. The analysis of these livelihoods thus requires a differentiated and multi-level research 
that examines the changes in socio-economic interaction patterns over time: it is based on empirical investigations into the evolution of households and community strategies, in which micro-level findings (the livelihood) are mirrored against the macro context (the political economy) to explain the social, economic and political factors relating to poverty and vulnerability. According to Sarah Collinson this analysis seeks to understand "both the political and the economic aspects of conflict, and how these combine to affect patterns of power and vulnerability" (2003). Just like any political economy analysis, it is concerned with the interaction of political and economic processes in a society, which include the distribution of power and wealth between different groups and individuals, and the processes that create, sustain and transform these relationships over time. In this context, the term vulnerability is not just being understood in terms of material need, but also includes an essential reference to (political and economic) powerlessness. Concepts like power and vulnerability are consequently not treated merely as natural or political fact, but are evaluated in terms of political and economic processes of negotiation. The view this approach encourages, therefore, is "dynamic and broad, longitudinal and explanatory" (ibid.).

Let me illustrate this methodology by one example. In eastern DRC, I came to the conclusion that ethnic trust is a vital aspect in enabling people's access to resources and markets: reference to ethnic belonging often is used to set up private commercial initiatives, to organize economic transactions and to acquire the necessary trust in commercial relations in general. At the same time however, I found out that this reference to ethnic belonging has become an important element in local recruitment strategies by local militias, who depend on the access to markets and resources for their own physical survival. Since the war, the social capital needed for the access to vital economic assets has thus become an essential element in realigning local economic interests altogether. The livelihoods approach made it easier to understand how the combination of a certain social asset (ethnic kinship) with a certain livelihood strategy (joining opposing militias) has had a detrimental effect on inter-communal solidarity as a whole.

\section{The Researcher as Subject}

During the research, a number of practical difficulties were encountered that sometimes seriously influenced the analysis (Vlassenroot and Raeymaekers 2004). In some regions (specifically in Ituri), I was confronted with a permanent difficulty - and sometimes even denial - in accessing the terrain. More important, however, was the varied quality of access during fieldwork. In some cases, it was almost impossible to go and talk to people without being accompanied by members of the rebel groups that was in control of the area. I particularly encountered this problem in Masisi, where interviews with vulnerable populations were meticulously followed by present armed forces. The level of interference by armed actors was therefore interpreted as a clear indicator of the problematic relationship that existed between vulnerable populations and political or military authorities. Also in Ituri, I was 'guided' by members of the local militia. In one particular village, it was only on one occasion that I succeeded to talk to someone without armed escort; even if this man was scared to talk to me, it was one of my best interviews in that area.

Furthermore, research into the broader political economy was often impeded by the more serious difficulty in acquiring information on violent, informal and "illegal" economic activities. This impediment related to the general problem of obtaining reliable 
statistical and official data on economic transactions. In line with previous research into this field, I therefore opted for using a "real economy" approach, which includes all recorded economic activity, as well as the non-monetized and reminder economic activity that is more or less illegal, inadmissible. This definition gave me the chance of explaining the more formal aspects of the economy, as well as the political dynamics underlying the informal trade and other informal economic activity. Finally, as for any livelihoods approach during chronic conflict situations, I encountered a difficulty in differentiating between the various livelihood and wealth groups in the studied sub-regions. As was discovered during the research, this difficulty was inherently related to the crisis situation: because of the permanent displacement of many populations, as well as a great variability of income due to continuous insecurity, most people were not able to provide a reliable estimate of their wartime incomes. This difficulty could be countered in part by setting a virtual time-frame for income estimates (for example by differentiating between pre-war and wartime situations, or between daily and monthly incomes), as well as by referring to more systematic and quantitative studies into the area of income distribution.

When discussing research methods, two additional observations need some specific attention. Both are related to the position of the researcher. The first one deals with the relationship between the researcher and his or her research subject or environment. The second one is the autonomy of the researcher. Although both issues risk putting considerable constraints on all social research, they become all the more relevant when working in highly charged political and conflict situations. Perhaps the most important issue was to remain indifferent to the context and some of the dimensions of what I was studying. As in some cases I got very close to those whom I tried to understand, I discovered that I tended to believe the accounts of some actors much more easily than I did with other accounts. The syndrome of having sympathy for the victims of violence is well known. I experienced a similar phenomenon vis-à-vis some of my respondents, of whom certain were very much involved in militias or rebel movements. I also found it difficult not to have "tacit support for those who are seen as, at any rate, less guilty than their opponents" (Clapham 1998: 18). At several occasions, members of warring groups even came to ask for advice, which made it extremely difficult not to cross the line between research and activism. They asked me about what strategy to follow and how to interpret certain politico-military events or the others' strategies. At one point, a good friend of mine even came to ask me if his community had to take up arms again and fight their way to political recognition. Of course my advice was to choose another option, but here I had become the researcher turned into political advisor.

Another drawback concerns a belief in the loyalty of respondents. This problem has several levels. It took some time before I realised that many of the respondents saw me as an important element in their strategies to attain certain objectives (my writings were used as proofs that their claims or grievances were justifiable), or had no faith in my research objectives. Even though I have always tried to explain what kind of information I was looking for and what was the purpose of my research, I sometimes found it difficult to convince people that I was not a spy on the payroll of intelligence services. In some cases, a lot of imagination and contacts were needed to escape arrest. Once I could not avoid this and was accused of being a spy for the Belgian intelligence office. Strangely enough, in 1999 a Belgian NGO also found it necessary to publish a statement from a civil society member from Bukavu stating that I was working for the CIA. Research, thus, is not necessarily viewed by local people as neutral and may have negative outcomes. 
Furthermore, those who became close friends did not tell me everything as I misleadingly expected. I later found out that this had not necessarily to do with a lack of confidence but was part of a strategy to protect themselves and me as well.

\section{Conclusions}

This article started from the generally accepted argument that research in conflict zones is strongly limited by security constraints. Without denying the limits of conflict environments, it was argued that it is possible to conduct research in war zones and that the success of such endeavour does not depend on the research context as such but on the skills and position of the researcher. Drawing upon experience gained from research in eastern Congo, it was claimed that a flexible research methodology, a good knowledge of the security context and a network of valuable local contacts are three conditions for successful empirical research in conflict regions. At the same time, researchers in these regions should be aware that their work is strongly influenced by the relationship with their research subject. The moment of the first arrival, the "syndrome of sympathy" and the faith in local respondents all pose some serious limits to research based on fieldwork in conflict zones.

\section{References}

Atkinson, Rowland and John Flint, 2001. "Accessing Hidden and Hard-to-Reach Populations: Snowball Research Strategies", in Social Research Update. University of Surrey, Issue 33.

Clapham, Christopher, 1998. "Introduction", in Christopher Clapham (ed.), African Guerillas. Oxford, Bloomington and Kampala: James Currey, Indiana University Press and Fountain Publishers.

Collinson Sarah et al., 2003. Power, Livelihoods and Conflict: Case Studies in Political Economy Analysis for Humanitarian Action, HPG Report, 13. London: Overseas Development Institute.

GoodHAND, Jonathan, 2000. "Research in conflict zones: ethics and accountability", Forced Migration Review, 8, p. 15.

JACQUEMIN, Alain, 1999. Urban Development and New Towns in the Third World. Lessons from the New Bombay Experience. Aldershot: Ashgate Publishing Ltd.

Vlassenroot, Koen and Tim Raeymaekers, 2004. Conflict and Social Transformation in eastern DR Congo. Ghent: Academia Press. 